\title{
Relationship between Accrual Anomaly and Stock Return: The Case of Vietnam
}

\author{
Hung Ngoc DANG ${ }^{1}$, Dung Manh TRAN ${ }^{2}$
}

Received: July 07, 2019 Revised: September 16, 2019 Accepted: September 24, 2019

\begin{abstract}
The study investigates the impact of accrual anomaly on stock return ratio of listed firms in Vietnam. Data were collected from listed firms for the period from 2008 to 2018. To learn about the causes of accrual anomaly in returns and future rate of returns on the Vietnamese stock market, this research is based on accrual analysis of Richardson, Sloan, Soliman, and Tuna (2006) on growth and effective components. We employ GLS regression model for examining the impact of accrual anomaly on stock return ratio and T-test for checking the difference between the lowest and the highest portfolio. The results show that accounting distortion is the main factor impacting the stock return, not growth determinant. Both two determinants of accounting distortion and growth contribute the explanation of the impact of accrual anomaly on profit and future stock return ratio. Experimental evidence confirms an abnormal existence of accrual in the Vietnam stock market. Aggregate accrual is negatively correlated with future operating profit and future stock return. However, after considering the factors contributing to the impact of future profitability and return on stock returns, the study results show that accounting distortion can account for low sustainability of income that is not growth.
\end{abstract}

Keywords : Accrual Anomaly, Stock Return, Growth, Accounting Distortion, Vietnam

JEL Classification Code : F65, G30, O16

\section{Introduction}

Previous accounting studies have proved an inverse correlation of accrual principles in accounting regarding future earnings and stock price returns. This relationship was first demonstrated in the US capital market by Sloan (1996). It is called accrual anomaly. He showed that listed firms with high accrual reports have low stock returns, whereas firms with low accrual reports have high stock returns. However, the nature of this anomaly still challenges modern theories and opens a promising path for empirical researches. Abnormal accruals directly test the capital market efficiency for publicly available accounting

1 First Author, Associate Professor, Hanoi University of Industry, Vietnam. [Postal Address: 298 Cau Dien Street, Bac Tu Liem District, Hanoi, 100000, Vietnam] Email: hungdangngockt@yahoo.com.vn

2 Corresponding Author, Associate Professor, National Economics University, Vietnam. [Postal Address: 207 Giai Phong Road, Hai Ba Trung District, Hanoi, 100000, Vietnam] Email: manhdung@ktpt.edu.vn

(c) Copyright: Korean Distribution Science Association (KODISA) This is an Open Access article distributed under the terms of the Creative Commons Attribution Non-Commercial License (http://Creativecommons.org/licenses/by-nc/4.0/) which permits unrestricted noncommercial use, distribution, and reproduction in any medium, provided the original work is properly cited. information. The general ability and cause of accounting irregularities, as well as their impact on market efficiency, continue to attract the attention of researchers such as Chudek, Truong, and Veeraraghavan (2011), Pincus, Rajgopal, and Venkatachalam (2007), Titman, Wei, and Xie (2013), Watanabe, Xu, Yao, and Yu (2013), and Nguyen, Dao, and Truong (2015). Most studies have discovered different aspects of accrual anomaly such as income sustainability, ability to forecast profitability, etc. in the US stock market. In this paper, we want to look for evidence to have a deeper look at the accrual anomaly, by analyzing a sample of firms listed on the Vietnam Stock Exchange. While the researchers agree on the existence of accrual anomaly, there is no consensus on its interpretation. Two main schools are divided, i.e. first, to study anomalies related to accounting distortions (Richardson, Sloan, Soliman, \& Tuna, 2005; Xie, 2001), and second, to study accrual anomaly related to growth factors (e.g., Fairfield, Whisenant, \& Yohn, 2003a, 2003b; Zhang, 2007; Wu, Zhang, \& Zhang, 2010).

LaFond (2005) provided part of the evidence related to the ability to predict the rate of return and exploit the income of accrual anomaly. Leippold and Lohre (2012) reported the impact of accrual business strategy on 
statistically significance gross profitability, but the anomalous rate of return is not statistically significant. Therefore, the negative relationship between the accrual of future returns on the UK stock market is still being debated.

Researches in an emerging and developing country have quite conflicting research results. Research of Kim, Kim, Kwon, and Lee (2015) pointed out that in contrast to developing countries, if using traditional accrual measure, there is no accrual anomaly in Korea. However, when changing the measurement to percent accruals, an accrual anomaly phenomenon is confirmed. Vivattanachang and Supattarakul (2013) studied in Thailand and found that the total accrual, cash flow and accrual were all priced correctly in the Thai market. Alqerm and Obeid (2014) have studied in Malaysia to show that income management through impact on cost is adjustable and production costs are negatively correlated with future securities yields.

In the context of Vietnam, there have been a number of related research on profit management, accrual anomaly such as researches of Dang, Hoang, and Tran (2017) and Dang, Do, Tran, Tran, and Ha (2018) but the results are still not clear, and the data time is short and incomplete. Hence, the question is that is there an accrual anomaly in Vietnam? and by what factors? This motivated us to scrutinize the issue of accrual anomaly in Vietnam. This study was carried out with two main objectives (i) considering the possibility of accrual anomaly in the Vietnamese stock market; (ii) provide empirical evidence of accrual anomaly related to growth determinants or accounting distortion.

\section{Literature Review and Research Hypotheses}

\subsection{Accrual Anomaly}

Sloan's study (1996) shows that firms with high accrual returns have low income efficiency and future rate of return, whereas firms with low accrual have high income efficiency and high future rate of return. Subsequent studies based on US data also provide evidence of its strong sustainability and the question is whether the effects of accrual anomaly also occur in other countries or not. According to a research by Richardson et al., $(2005,2006)$ and a review of the total accrual performance (such as changes in net operating assets ...), it is seen as a more comprehensive accrual measure than the use of accrual in working capital in other studies of accrual anomaly.

Pincus et al. (2007) examined stock markets in 20 countries during the period of 1993 - 2001 to determine whether accrual anomaly according to Sloan (1996), characterized by the role of accruals to make prices too high or too low. The results show that accrual anomaly can be generalized in other capital markets, low sustainability accrual in 13 of the 19 countries (except the US) and produces unusually high rates of return in 10 of these 19 countries. LaFond (2005) studied the effects of accrual on the rate of in large capital markets. Analysis results in specific countries showed that in 15 out of 17 countries, the abnormal rate of return is in a preventative manner and statistically significant. He concluded that accrual anomaly is a global phenomenon. Leippold and Lohre (2012) consider accrual in mispricing leading to the rate of returns, by collecting a sample of firms in 26 stock markets from May 1994 to April 2008. He found statistically significant evidence of anomalous rate of return in some countries. So we give a hypothesis as below:

Hypothesis 1: Accrual anomaly occurs in the Vietnamese stock market.

\subsection{Accrual Anomaly Analysis}

This paper will use analysis of accruals regarding growth and distortion of accounting (Richardson et al., 2006). There are two schools relating to accruals as:

The first direction of the study is the view that accrual anomaly can be explained by fixed income. Sloan (1996) hypothesizes that naive investors focus on below income and do not understand low sustainability of the accrual components of income. Therefore, investors highly value firms with high accruals. For firms with low accruals, it's the opposite. He surmised that low sustainability of the accrual component of income was due to subjectivity in estimating accrued amounts. Xie (2001) analyzes the accrual model of Jones (1991), which includes non-arbitrary (normal) and arbitrary (unusual) components that show that Sloan's results are a premise for future studies. Both studies explain unusual accrual due to management opportunism with the assumption that directors exploit arbitrary accruals to regulate income. Dechow and Dichev (2002) consider the new aspect of the quality of working capital and income accruals. They argued that the quality of accruals and earnings reduces the level of error estimation in accruals. $\mathrm{He}$ measures the accrual quality by residuals from specific regression models of changes in past, present and future working capital. The results show that the quality of accruals is positively related to income sustainability. This proves that firms with low cumulative earnings are unstable. Richardson et al. (2005) evaluate accountability of accruals and conclude that less reliable accrual leads to low income sustainability. Moreover, investors do not predict that the low sustainability of income significantly affect the ability to forecast stock returns.

The second direction of the study is the view that accrual anomaly can be interpreted as a more general growth anomaly. Fairfield et al. (2003a) pointed out that accrual is not only components of current profit but also growth. Working capital accruals, long-term accruals and total accruals are as per short-term asset growth, long-term assets and net operating assets. Fairfield et al. (2003a) found no statistically significant difference in the negative relationship between future long-term working capital accruals with income efficiency and stock return. Based on 
these findings, Fairfield et al. (2003a) predict that the low sustainability of accruals arises from the interaction between firm growth and the slow rate of economic returns associated with a gradual reduction in marginal return on growth in investment. At the same time, they believe that investors misunderstand the impact of growth on future income efficiency, leading to serious mispricing. In the next study, Fairfield et al. (2003b) argued that the low sustainability of accruals relates to the free cash flow growth in investment but not income growth. Zhang (2007) showed that the accrual anomaly tends to be unusually large when the accrual was more likely to measure growth.

In short, the evidence from these studies cannot be used to conclude on the fundamental origin of accrual anomaly. The first direction shows the low sustainability of accruals due to accounting distortion, while the second is related to growth. Both directions assume some unreasonable models to explain the impact of accrual on stock returns. Naive investors ignore the effects of accounting factors and growth of future income efficiency, leading to serious mispricing. However, we cannot rule out the possibility that accrual anomaly can be affected by both accounting and growth factors. Regarding the low sustainability of accruals, Dechow, Richardson, and Sloan (2008) argued that a gradual reduction in the rate of return for new investments or overinvestments could coexist with the sensitivity of accruals due to measurement errors, because of generally accepted accounting principles require an immediate decline of most non-profit investments. Richardson et al. (2006) show that both growth factors and accounting distortions can explain low sustainability of US stock market accruals.

Concerning the impact of accrual on stock returns from the wrong valuation point of view, according to Shi and Zhang's argument (2012), anomaly in growth may be consistent with fixed income in a some degree. Explaining the growth anomaly is still controversial in the research literature of Dechow and Sloan (1997), which suggests that anomaly growth is due to the expected investor error. Sloan (1996) found that firms' anomalous rates of return have a negative relationship with the high accruals concentrated around future earnings announcements. Bradshaw, Richardson, and Sloan (2001) showed that the forecast of financial analysts is related to the optimism of firms with high accrued amounts. Therefore, it can be argued that anomalous growth may arise from fixed income of investors. Theoretically, in this case, accounting and growth distortion can complement each other in promoting the impact of accrual on both income and future stock return. Such a possibility may also come from income management incentives. The CEO of the company with increasing investment or overinvestment can adjust the income, making the profitability ratio decrease gradually because of little attention from investors (Polk \& Sapienza, 2008). So we design hypotheses as below:

Hypothesis 2: Low sustainability of accrual components in income is due to accounting distortion or growth.
Hypothesis 3: The impact of accrual on stock return is due to accounting distortion or growth.

\section{Research Methodology}

\subsection{Accrual Measurement}

Previous studies on the possibility of accrual anomaly in the stock market have used working capital accrual as a fundamental accrual measure. The accrual of working capital is defined as a change in short-term net working capital assets without depreciation costs (Healy, 1985). However, this measure is relatively narrow, as it ignores the accrual of long-term assets (software development costs, capital costs, long-term receivables). Richardson et al. (2005) gave a broader definition of accrual, which is to combine all the differences between GAAP income and cash income. In order to build a comprehensive accrual measure, they began by noting the case of accrual accounting. Asset and liabilities accounts appear on the balance sheet are cash accounts. The remaining assets and other liabilities are the output of accrual accounting.

This comprehensive definition of accrual differs from the definition used by (Healy, 1985), Sloan (1996) and others in some important respects. First, this definition incorporates accrued long-term assets, such as cost of capital. Healy's definition (1985) ignores the source of long-term accruals and incorporates only a subset of long-term asset accruals minus depreciation costs. Second, the definition of accruals incorporates long-term liabilities-related accruals, such as retirement benefits. Third, it incorporates accrued financed assets, such as long-term receivables. Finally, the definition of accruals incorporates financial accruals related to financial liabilities, such as long-term debt. Therefore, according to Richardson et al. (2005, 2006), the definition of accrual includes changes in long-term assets / liabilities (long-term accruals). By this definition, the total accrual (ACC) represents the percentage change in net assets (NOA).

We use the indirect method to calculate the total accrual (ACC) according to the percentage change in the net operational asset (NOA).

$$
\begin{gathered}
N O A_{t}=\left(T A_{t}-C_{t}\right)-\left(T A_{t}-M I N T_{t}-O P S_{t}-T D_{t}\right) \\
A C C_{t}=\frac{\Delta N O A_{t}}{N O A_{t-1}}
\end{gathered}
$$

In which:

$T A_{t}$ is total assets;

$C_{t}$ is cash and equivalents;

$M I N T_{t}$ is the benefit of uncontrolling shareholders;

$O P S_{t}$ is ordinary and preferred stock;

$T D_{t}$ is total debt. 
For the analysis of accounting distortion, sale growth (SG) is calculated by the ratio of the change in revenue and the change in the NOA (AT) sale rate given by the formula:

$$
\begin{gathered}
S G_{t}=\frac{\left(\text { Sales }_{t}-\text { Sales }_{t-1}\right)}{\text { Sales }_{t-1}} \\
\frac{\Delta A T_{t}}{A T_{t}}=\frac{\frac{\text { Sales }_{t}}{\text { NOA }_{t}}-\frac{\text { Sales }_{t-1}}{\text { NOA }_{t-1}}}{\frac{\text { Sales }_{t-1}}{N O A_{t-1}}}
\end{gathered}
$$

We rely on research of Richardson et al., (2006), using current operating profit and operating profit next year (Profit on net operating assets - RNOA) calculated as follows:

$$
\operatorname{RNOA}_{t}=\frac{\text { Operating Profit }}{t}
$$

\subsection{Analysis of Growth and Efficiency}

To learn about the causes of accrual anomaly in returns and future rate of returns on the Vietnamese stock market, this research is based on accrual analysis of Richardson et al. (2006) on growth and effective components. This analysis allows the distinction between the role of growth and accounting distortion to be factors that contribute to accrual anomaly. According to the definition of total accrual (ACC), the net operating asset change has been downgraded by the latency of the operating asset:

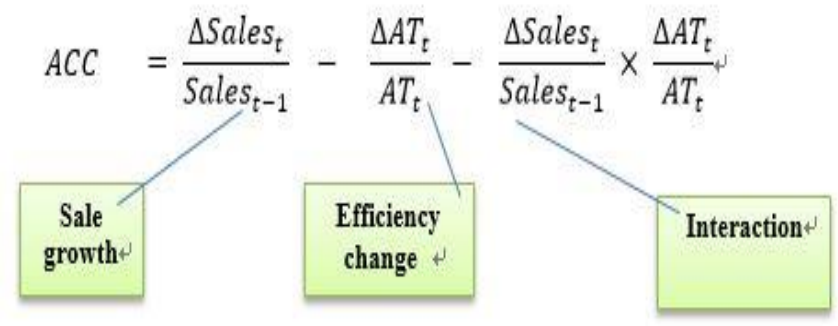

First, the total accrual is directly related to sales growth (SG). If asset efficiency remains unchanged, the increase in sales will lead to an increase in the total accrual. Second, the total accrual has an inverse relationship with the effective component of accrual (AT). In the absence of sales growth, the decline in asset efficiency will lead to an increase in total accrual. The analysis also includes interaction between growth and efficiency components. This indicates that simple linear analysis is not appropriate when sales growth and efficiency change components are correlated. The economy of scale indicates a positive relationship between sales growth and efficiency change. In addition, the declining marginal rate of return represents an inverse relationship because increasing sales leads to lower selling prices, which in turn leads to a decrease in sales. Richardson et al. (2006) argued that if accruals reflect an increase in investment, then growth will lead to higher sales, whereas if there is an increase in accrual, there is no change in sales. The increase in this accrual may be due to a decline in the efficiency of the component, or due to accounting distortion or less efficient use of capital.

Richardson et al. (2006) argued that accrual is positively related to sales growth. If the efficiency of the asset does not change, sales increase will lead to increased accrual. Analysis of Richardson et al. (2006) shows that the accrual is inversely related to the effective component. Since there is no revenue growth, effective component reduction results in increased accrual. Thus, the effective component is expected to have a positive relationship with the future rate of return, firms with low efficiency components are expected to earn low future rates of return.

\subsection{Measurement of Stock Return Ratio}

In order to calculate each company's annual stock return ration, we first collect stock prices at the end of each year $(\mathrm{Pt})$. In case the company pays dividends (Dt) during the year, the share rate of return will include stock price which will include the final price plus dividends paid per share. The stock's return ration at the time of year $t$ is calculated as follows:

$$
\operatorname{RET}_{t}=\frac{\left(P_{t}-P_{t-1}\right)+D_{t}}{P_{t-1}}
$$

\subsection{Research Model}

To distinguish between ways of interpreting low sustainability of accrual components in accounting profits, this profit is made by the appropriate method of investment capital and therefore expressed as an accounting rate of return according to Richardson et al. (2006). This result confirms $\beta 2<0$ according to the following equation:

$$
R N O A_{t+1}=\beta_{0}+\beta_{1} R N O A_{t}+\beta_{2} A C C_{t}+\varepsilon_{t+1}
$$

In which:

$R N O A_{t+1}$ : accounting rate of return at time $t+1$

$R N O A_{t}$ : accounting rate of return at time $t$

$A C C_{t}$ : accrual component of the accounting rate of return at time $t$

$\varepsilon_{t+1}$ : residual at time $t+1$, assuming an average value of 0 and no correlation with $R N O A_{t}, A C C_{t}$.

From an intuitive point of view, this result shows the following experimental principle: Firms with high accrual value at the present time tend to have high accounting rates at the present time, but that tend to be significantly reduced at the next time. Similarly, to explain the low sustainability of the cumulative component for the stock returns by the following equation: 


$$
R E T_{t+1}=\beta_{0}+\beta_{1} R N O A_{t}+\beta_{2} A C C_{t}+\varepsilon_{t+1}
$$

In which:

$R E T_{t+1}:$ rate of return at time $t+1$

With $\beta_{2}<0$, firms with high accrual tend to have high stock yield decline. After that, the total accrual (ACC) is separated into growth components, effective ingredients and interactive components with the following equations:

$$
\begin{aligned}
& R N O A_{t+1}=\beta_{0}+\beta_{1} R N O A_{t}+\beta_{2} S G_{t}-\beta_{3} A T_{t}-\beta_{4}\left(S G_{t}\right. \\
&\left.* \Delta A T_{t}\right)+\varepsilon_{t+1} \\
& R E T_{t+1}=\beta_{0}+ \beta_{1} R N O A_{t}+\beta_{2} S G_{t}-\beta_{3} \Delta A T_{t}-\beta_{4}\left(S G_{t}\right. \\
&\left.* \Delta A T_{t}\right)+\varepsilon_{t+1}
\end{aligned}
$$

$\beta_{2}<0$ indicates that firms with high growth rates tend to have lower rates of return.

$\beta_{3}>0$ indicates that high efficiency capital firms tend to have high stock returns.

$\beta_{4}$ is the interaction between growth and efficiency. If $\beta_{4}<0$ indicates the dominant growth component, $\beta_{4}>0$ represents the dominant component.

The correlation between variables and the expected sign are presented as below:

\begin{tabular}{|c|c|c|c|}
\hline & $A C C_{t}$ & $R N O A_{t+1}$ & $R E T_{t+1}$ \\
\hline$A C C_{t}$ & & - & - \\
\hline$S G_{t}$ & + & - & - \\
\hline$\Delta A T_{t}$ & - & + & + \\
\hline
\end{tabular}

(i) $A C C_{t}$ has a negative relationship with $R N O A_{t+1}$, $R E T_{t+1}$ : High accrual firms are expected to have low profitability.

(ii) $S G_{t}$ has a positive relationship with $A C C_{t}$ : If the effective component does not change, increase in sales will lead to accrual gains and vice versa, declining sales lead to reduced accrual.

(iii) $S G_{t}$ has a negative relationship with $R E T_{t+1}$ : Firms that have low sales growth will have a high profitability rate.

(iv) $\triangle A T_{t}$ has a negative relationship with $A C C_{t}$ : Due to the fact that there is no sales growth, the reduction of effective ingredients will increase accrual.

(v) $\Delta A T_{t}$ has a positive relationship with $R E T_{t+1}$ : Firms that have low efficiency are expected to have a low future rate of return.

\subsection{Research Data}

Research data includes 579 firms listed on the Vietnam Stock Exchange, with financial statements and market data (profitability rate, capitalization) collected from two websites which are cophieu68.vn and cafef.vn in the period between 2008 and 2018 (unbalanced data). Banks, insurance firms, financial firms and investment funds, delisted firms, firms with uncontinuous past data are excluded from the research sample. In addition, the study also eliminates the observations of firms with insufficient data to calculate total accrual, components of accrual, current and next year operating profit.

This research also employs GLS regression model to examine the impact of accrual on future profit and stock return rates. After that, we continue to use this method to consider the contribution of growth and accounting distortions related to the impact of accrual on profit and stock return. At the same time, to consider the difference between the lowest and the highest portfolio, we use the $\mathrm{T}$ test to examine them.

\section{Results and Discussion}

Statistical data (Table 1) show that the average stock return rate $\left(R E T_{t+1}\right)$ averages $24.6 \%$, future accounting operating profit $\left(R N O A_{t+1}\right)$ and current accounting operating profit $\left(R N O A_{t}\right)$ averages $22.1 \%$ and $22.2 \%$ respectively. The average accrual value $(A C C)$ is 0.132 , the minimum is -1.151 and the highest is 2,020. Average sale growth $(S G)$ is $5.9 \%$, effective change factor $(\triangle A T)$ has an average value of 0.132 , Interactive factor has an average value of 0.169 .

Table 1: Descriptive Analysis

\begin{tabular}{|l|c|c|c|c|c|}
\hline Variables & $\begin{array}{c}\text { Observa } \\
\text {-tions }\end{array}$ & Mean & $\begin{array}{c}\text { Standard } \\
\text { Devidation }\end{array}$ & Min & Max \\
\hline $\mathrm{RET}_{\mathrm{t}+1}$ & 4,265 & 0.246 & 0.504 & -0.471 & 1.580 \\
\hline $\mathrm{RNOA}_{\mathrm{t}+1}$ & 4,265 & 0.221 & 0.585 & -1.002 & 1.979 \\
\hline $\mathrm{RNOA}_{\mathrm{t}}$ & 4,265 & 0.222 & 0.591 & -1.002 & 1.979 \\
\hline $\mathrm{ACC}$ & 4,265 & 0.132 & 0.675 & -1.151 & 2.020 \\
\hline $\mathrm{SG}$ & 4,265 & 0.129 & 0.351 & -0.434 & 1.210 \\
\hline$\Delta \mathrm{AT}$ & 4,265 & 0.132 & 5.117 & -13.527 & 14.485 \\
\hline $\mathrm{GS}^{*} \mathrm{AT}$ & 4,265 & 0.169 & 1.169 & -2.521 & 4.067 \\
\hline
\end{tabular}

The results in Table 2 show the correlation matrix between financial variables. The growth and efficiency component has a positive relationship with the correlation coefficient of 0.0461 , indicating that firms growing will increase asset turnover in accordance with the size of the economy. This relationship indicates the important role for both components in explaining accrual anomaly. In addition, the correlation coefficient 0.0461 shows the positive relationship between the components of $S G$ and $A C C$, while $\triangle A T$ has a negative relationship with $A C C$ with a coefficient of -0.3017 
Hung Ngoc DANG, Dung Manh TRAN / Journal of Asian Finance, Economics and Business Vol 6 No 4 (2019) 19-26

Table 2: Coefficient Matrix

\begin{tabular}{|c|c|c|c|c|c|c|c|}
\hline & RET $_{t+1}$ & $\mathrm{RNOA}_{\mathrm{t}+1}$ & $\mathrm{RNOA}_{t}$ & ACC & SG & $\Delta$ AT & GS*AT \\
\hline $\operatorname{RET}_{t+1}$ & 1 & & & & & & \\
\hline $\mathrm{RNOA}_{\mathrm{t}}$ & 0.0186 & 0.4053 & 1 & & & & \\
\hline$S G$ & -0.018 & 0.0361 & 0.0975 & 0.1829 & 1 & & \\
\hline$\Delta \mathrm{AT}$ & 0.022 & 0.3611 & -0.3506 & -0.3017 & 0.0461 & 1 & \\
\hline GS*AT & -0.006 & 0.1527 & -0.139 & -0.1761 & 0.137 & 0.3073 & 1 \\
\hline
\end{tabular}

Table 3 results show evidence of low sustainability of stock market accrual in Vietnam. With the results of future RNOA regression based on the current RNOA and ACC. ACC's coefficient $\beta_{2}$ represents the difference between the accrual component and the RNOA cash component. Consistent with previous studies, the coefficient $\beta_{2}=$ -0.141 at the $1 \%$ significance level confirms the low sustainability of accrual in Vietnam. At the same time, the result of Table 2 shows the negative relationship between ACC and the stock return rate $\left(R E T_{t+1}\right)$, which is illustrated by a coefficient of -0.0390 . Thus, the results found in Table 2 provide evidence for the $\mathrm{H} 1$ hypothesis, indicating that there is an accrual anomaly in the Vietnamese stock market.

Table 3: Results Regression - Profit and stock return ratio in the future

\begin{tabular}{|c|c|c|}
\hline & RNOA $_{t+1}$ & RET $_{t+1}$ \\
\hline \multirow[t]{2}{*}{$\mathrm{RNOA}_{\mathrm{t}}$} & $0.428^{\star \star \star}$ & 0.0197 \\
\hline & [30.94] & [1.48] \\
\hline \multirow[t]{2}{*}{ ACC } & $-0.141^{\star \star \star}$ & $-0.0390^{\star \star \star}$ \\
\hline & [-11.62] & {$[-3.36]$} \\
\hline \multirow[t]{2}{*}{ _cons } & $0.145^{\star \star \star}$ & $0.247^{\star * \star}$ \\
\hline & [16.68] & [28.88] \\
\hline $\mathrm{N}$ & 4265 & 4265 \\
\hline
\end{tabular}

In Table 4, first, we consider the regression results of the growth component with future operating profit. The coefficient of $-0.00578(t=-0.25)$ is not statistically significant, indicating that the growth component does not contribute to the impact of cumulative profit on future operating profit. Next, we consider whether the effective component contributes to the impact of accrual on future operating profit or not. With a coefficient of $\triangle A T$ of 0.0656 ( $t=47.45$ ), it is statistically significant. Therefore, accounting distortion contributes to the low sustainability of accruals in Vietnam. The GS *AT interaction component with a coefficient of $0.107(t=15.50)$ has been implicated in the interpretation of low sustainability. The final model with a complete combination of growth components, effective ingredients and interactive components produces results showing that all components have an impact on future operating profit. In particular, the growth component has a negative impact on future operating profits, while the effective component, and the corresponding component, are positively related to future operating profit. The results of this study are consistent with the study of Richardson et al. (2006).

Table 4: Results Regression - Future profit with growth and accounting distortion

\begin{tabular}{|c|c|c|c|c|}
\hline & $\mathrm{RNOA}_{\mathrm{t}+1}$ & $\mathrm{RNOA}_{\mathrm{t}+1}$ & RNOA $_{t+1}$ & $\mathrm{RNOA}_{\mathrm{t}+1}$ \\
\hline \multirow[t]{2}{*}{$\mathrm{RNOA}_{\mathrm{t}}$} & $0.402^{\star \star \star}$ & $0.600^{\star \star \star}$ & $0.430^{\star \star \star}$ & $0.611^{\star \star \star}$ \\
\hline & [28.84] & [50.15] & [31.63] & [50.93] \\
\hline \multirow[t]{2}{*}{ SG } & -0.00578 & & & $-0.100^{\star \star \star}$ \\
\hline & {$[-0.25]$} & & & {$[-5.25]$} \\
\hline \multirow[t]{2}{*}{$\Delta \mathrm{AT}$} & & $0.0656^{\star \star \star}$ & & $0.0637^{\star \star \star}$ \\
\hline & & [47.45] & & [44.49] \\
\hline \multirow[t]{2}{*}{ GS*AT } & & & $0.107^{\star \star \star}$ & $0.0378^{\star \star \star}$ \\
\hline & & & [15.50] & [6.33] \\
\hline \multirow[t]{2}{*}{ Cons } & $0.133^{\star \star \star}$ & $0.0795^{\star \star \star}$ & $0.108^{\star * *}$ & $0.0840^{* * *}$ \\
\hline & [14.50] & [11.09] & [12.44] & [11.26] \\
\hline $\mathrm{N}$ & 4,265 & 4,265 & 4,265 & 4,265 \\
\hline
\end{tabular}

t statistics in brackets ${ }^{*} p<0.1,{ }^{\star \star}{ }^{*}<0.05,{ }^{* \star}{ }^{* \star} p<0.01$

After that, we consider extending the analysis of accrual anomaly to future rate of return. Table 5 presents the results for future stock yield ratios (next year), showing that there is a positive effect and a 5\% statistical significance.

Table 5: Results Regression - Future stock return ratio with growth and accounting distortion

\begin{tabular}{|c|c|c|c|c|}
\hline & RET $_{t+1}$ & RET $_{t+1}$ & RET $_{t+1}$ & RET $_{t+1}$ \\
\hline \multirow[t]{2}{*}{ RNOA } & 0.0175 & $0.0256^{\star}$ & 0.0154 & $0.0277^{\star \star}$ \\
\hline & [1.34] & [1.83] & {$[1.17]$} & {$[1.97]$} \\
\hline \multirow[t]{2}{*}{ SG } & -0.0287 & & & -0.0309 \\
\hline & {$[-1.30]$} & & & {$[-1.38]$} \\
\hline \multirow[t]{2}{*}{$\Delta \mathrm{AT}$} & & $0.00320^{\star \star}$ & & $0.00369^{\star \star}$ \\
\hline & & [1.99] & & [2.20] \\
\hline \multirow[t]{2}{*}{ GS*AT } & & & -0.0015 & -0.00433 \\
\hline & & & {$[-0.22]$} & {$[-0.62]$} \\
\hline \multirow[t]{2}{*}{ cons } & $0.246^{\star \star \star}$ & $0.240^{\star \star \star}$ & $0.243^{\star \star \star}$ & $0.244^{\star * *}$ \\
\hline & [28.48] & [28.77] & [28.97] & [27.93] \\
\hline $\mathrm{N}$ & 4265 & 4265 & 4265 & 4265 \\
\hline
\end{tabular}

t statistics in brackets ${ }^{*} p<0.1,{ }^{* *} p<0.05,{ }^{* * *} p<0.01$

The inclusion of the growth component of accrual does not contribute to the low sustainability of profits. If the negative relationship between accrual and profitability is due to the growth component, leading to misunderstandings on the part of investors regarding decreasing marginal return which lead to increase in investment, this is not considered as an explanation for accrual anomaly. As we explained in the theoretical basis, a possibility considered more 
appropriate is the explanation that the optimal investment executives respond to the decreased discount rate, which will lead to the negative relationship between accruals and stock returns. On the other hand, the effective component of such accrual requires consideration of which components are dominant or major in predicting future stock returns. The results were consistent with the studies of Fairfield et al. (2003a); and Richardson et al. (2006).

The results in Table 6 after the components are arranged according to $A C C$ decomposition list showing the direction of the growth component $(S G)$, the effective component $(\triangle A T)$, the future operating profit ratio $\left(R N O A_{t+1}\right)$, future stock return rate $\left(R E T_{t+1}\right)$. The results show that growth components tend to increase in the same direction with $A C C$, effective components tend to decrease compared to $A C C$. Future operating profit ratio components, future stock yield ratios have unstable trends. There are differences and statistically significant at the $1 \%$ level between the lowest and the highest level.

Table 6: Features of portfolio based on total accrual

\begin{tabular}{|c|c|c|c|c|c|}
\hline & ACC & SG & $\Delta$ AT & $\mathrm{RNOA}_{\mathrm{t}+1}$ & RET $_{t+1}$ \\
\hline ACC1_L & -0.969 & 0.076 & 3.008 & 0.480 & 0.279 \\
\hline ACC3 & -0.202 & 0.078 & 0.911 & 0.275 & 0.270 \\
\hline ACC5 & 0.002 & 0.088 & 0.137 & 0.130 & 0.288 \\
\hline ACC6 & 0.094 & 0.102 & -0.037 & 0.132 & 0.226 \\
\hline ACC7 & 0.206 & 0.159 & -0.163 & 0.138 & 0.250 \\
\hline ACC10_H & 1.647 & 0.280 & -3.107 & 0.202 & 0.203 \\
\hline \multirow{2}{*}{$\begin{array}{l}\text { Difference } \\
\text { L-H }\end{array}$} & -2.61 & -.2039 & 6.115 & .0671 & .0758 \\
\hline & $(-12,234)^{\star \star \star}$ & $(-7.6741)^{\star \star \star}$ & $(9.0495)^{\star \star \star}$ & $(-4.840)^{\star \star \star}$ & $(2.2533)^{\star \star}$ \\
\hline
\end{tabular}

t statistics in brackets ${ }^{*} p<0.1,{ }^{\star *} p<0.05,{ }^{* \star *} p<0.01$

\section{Conclusions and Recommendations}

The results show that accounting distortion is the main cause of the low sustainability of incomes that are not growth components. However, both of these components contribute to explaining the impact of accrual anomaly on stock returns. The results provided evidence that hypotheses $\mathrm{H} 1, \mathrm{H} 2$ and $\mathrm{H} 3$ are accepted.

This paper examines the existence of an accrual anomaly of stocks in the Vietnamese stock market and analyzes the factors affecting the stock return rate. We measure total accrual, combined with long-term accruals that are considered to be contributing to accrual. According to the analysis of total accrual (Richardson et al., 2006), the study can distinguish the role of accounting-based and growthbased factors. Experimental evidence confirms an abnormal existence of accrual in the Vietnam stock market. Aggregate accrual is negatively correlated with future operating profit and future stock return. However, after considering the factors contributing to the impact of future profitability and return on stock returns, the study results show that accounting distortion can account for low sustainability of income that is not growth. The study results also found that it is possible to explain the growth component and the effective component of the accumulation contribute to the impact on stock returns. The findings of the study are consistent with the mispricing of accounting distortions to profitability. Thus, high valuations of investors are related to accrual because of the accounting distortion. High valuation of accounting distortions can reduce financial difficulties leading to increased investment value of executives as a reasonable response to reduce capital costs. Our evidence with explanations may be appropriate for the unusual accumulation of Vietnamese stock market.

Limitations of this paper are the fact that principles of accruals in accounting are determined based on the accounting system and the application of accounting standards. In different countries, the measurement method may be different, resulting in research results may not be the same. At the same time, the two components of growth and accounting distortion still have many other factors affecting future profit and profitability, but the study only considers these two components, so it cannot reflect exactly the impact on profitability and stock returns.

\section{Reference}

Alqerm, J. F., \& Obeid, S. N. S. (2014). The pricing of the real earnings management evidence from Malaysian Stock Exchange. Journal of Al-Quds Open University, 333(2295), 1-43.

Bradshaw, M. T., Richardson, S. A., \& Sloan, R. G. (2001). Do analysts and auditors use information in accruals? Journal of Accounting Research, 39(1), 45-74.

Chudek, M., Truong, C., \& Veeraraghavan, M. (2011). Is 
trading on earnings surprises a profitable strategy? Canadian evidence. Journal of International Financial Markets, Institutions and Money, 21(5), 832-850.

Dang, N. H., Hoang, T. V. H., \& Tran, M. D. (2017). Factors affecting earnings management: The case of listed firms in Vietnam. International Journal of Economic Research, 14(20), 117-134.

Dang, N. H., Do, H. L., Tran, T. V. H., Tran, M. D., \& Ha, T. T. V. (2018). Factors influencing accrual earnings management and real earnings management: The case of Vietnam. Paper presented at the International Conference on Humanities and Social Sciences, Khon Kaen University, Thailand.

Dechow, P. M., \& Dichev, I. D. (2002). The quality of accruals and earnings: The role of accrual estimation errors. The Accounting Review, 77(s-1), 35-59.

Dechow, P. M., Richardson, S. A., \& Sloan, R. G. (2008). The persistence and pricing of the cash component of earnings. Journal of Accounting Research, 46(3), 537566.

Dechow, P. M., \& Sloan, R. G. (1997). Returns to contrarian investment strategies: Tests of naive expectations hypotheses. Journal of Financial Economics, 43(1), 3-27.

Fairfield, P. M., Whisenant, J. S., \& Yohn, T. L. (2003a). Accrued earnings and growth: Implications for future profitability and market mispricing. The Accounting Review, 78(1), 353-371.

Fairfield, P. M., Whisenant, S., \& Yohn, T. L. (2003b). The differential persistence of accruals and cash flows for future operating income versus future profitability. Review of Accounting Studies, 8(2-3), 221-243.

Healy, P. M. (1985). The effect of bonus schemes on accounting decisions. Journal of Accounting and Economics, 7(1), 85-107.

Jones, J. J. (1991). Earnings management during import relief investigations. Journal of Accounting Research, 29(2), 193-228. doi:DOI: 10.2307/2491047

Kim, Y. J., Kim, J. H., Kwon, S., \& Lee, S. J. (2015). Percent accruals and the accrual anomaly: Korean evidence. Pacific-Basin Finance Journal, 35, 340-366.

La Porta, R. (1996). Expectations and the cross-section of stock returns. The Journal of Finance, 51(5), 1715-1742.

La Porta, R., Lakonishok, J., Shleifer, A., \& Vishny, R. (1997). Good news for value stocks: Further evidence on market efficiency. Journal of Finance, 859-874.

LaFond, R. (2005). Is the accrual anomaly a global anomaly? MIT Sloan School of Management Working paper 455$05 . \quad$ Available at: https://papers.ssrn.com/sol3/papers.cfm?abstract_id=782 726\&download=yes.

Lakonishok, J., Shleifer, A., \& Vishny, R. W. (1994). Contrarian investment, extrapolation, and risk. The Journal of Finance, 49(5), 1541-1578.

Leippold, M., \& Lohre, H. (2012). Data snooping and the global accrual anomaly. Applied Financial Economics, 22(7), 509-535.

Nguyen, T. T., Dao, T. T. G., \& Truong, H. H. (2015). The determinants of merger withdrawals' abnormal returns in the Australian market. Journal of Economics and Development, 17(3), 89-110.

Pincus, M., Rajgopal, S., \& Venkatachalam, M. (2007). The accrual anomaly: International evidence. The Accounting Review, 82(1), 169-203.

Polk, C., \& Sapienza, P. (2008). The stock market and corporate investment: A test of catering theory. The Review of Financial Studies, 22(1), 187-217.

Richardson, S. A., Sloan, R. G., Soliman, M. T., \& Tuna, I. (2005). Accrual reliability, earnings persistence and stock prices. Journal of Accounting and Economics, 39(3), 437-485.

Richardson, S. A., Sloan, R. G., Soliman, M. T., \& Tuna, I. (2006). The implications of accounting distortions and growth for accruals and profitability. The Accounting Review, 81(3), 713-743.

Shi, L., \& Zhang, H. (2012). Can the earnings fixation hypothesis explain the accrual anomaly? Review of Accounting Studies, 17(1), 1-21.

Sloan, R. G. (1996). Do stock prices fully reflect information in accruals and cash flows about future earnings? Accounting Review, 71(3), 289-315.

Titman, S., Wei, K. J., \& Xie, F. (2013). Market development and the asset growth effect: International evidence. Journal of Financial and Quantitative Analysis, 48(5), 1405-1432.

Vivattanachang, D., \& Supattarakul, S. (2013). The earnings persistence and the market pricing of earnings and their cash flow and accrual components of Thai firms. Journal of Accounting Profession, 9(25), 63-79.

Watanabe, A., Xu, Y., Yao, T., \& Yu, T. (2013). The asset growth effect: Insights from international equity markets. Journal of Financial Economics, 108(2), 529-563.

Wu, J., Zhang, L., \& Zhang, X. F. (2010). The q-theory approach to understanding the accrual anomaly. Journal of Accounting Research, 48(1), 177-223.

Xie, H. (2001). The mispricing of abnormal accruals. The Accounting Review, 76(3), 357-373.

Zhang, X. F. (2007). Accruals, investment, and the accrual anomaly. The Accounting Review, 82(5), 1333-1363. 